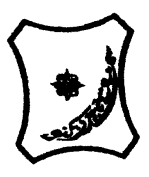

Bayero Journal of Pure and Applied Sciences, 11(1): 208 -213

ISSN 2006 - 6996

\title{
QUANTITATIVE ANALYSIS OF PLANT SPECIES DIVERSITY IN KANO ZOOLOGICAL GARDEN
}

\author{
Haruna, H., Aliko, A.A., Zakari, S.M. and Omeiza, A.H. \\ ${ }^{1}$ Department of Plant Biology, Bayero University Kano \\ *Correspondence author: hajarah556@yahoo.com, 08033887556
}

\begin{abstract}
The study was necessitated by the fact that quantitative floristic inventories provide necessary context for planning and interpreting long-term ecological research. It's also needed in conservation biology more than ever as an increasing number of threatened species find their way onto international and national "red lists". Objective evaluation of population decline and extinction probability is required for sound decision making. Long-term studies of tree population dynamics are critical for our understanding of the conservation needs of tropical forest ecosystems. The study analyzed the present Phyto-sociological, primary and secondary ecological parameters, plant species richness, dominance, similarities and pattern of plant species diversity status in selected habitats in Kano zoological garden. The dominant plant species were found to be Azadirachta indica which have the highest frequency, low frequency were observed in Zizipus spina-christi, Magnifera indica and Adansonia digitata

Keywords: Plant, Diversity, Azadirachta indica, Richness
\end{abstract}

INTRODUCTION

Ecologists frequently refer to their subject of study as a system that they investigate. A group of potentially interbreeding individuals of the same organism (a population) is a system; an assemblage of different species in a given area (a community) is a system; and a large area of land containing many populations of organisms arranged in different local communities over areas with unique abiotic environments is also a system (an ecosystem). All ecological systems share two important traits, structure and function. The structure of a system is defined by its measurable traits at a single point in time and can include living (biotic) and non-living (abiotic) components (e.g. plant height, plant morphology, and plant distribution). The functions of an ecological system involve the various processes that occur as the component parts exchange energy through time (e.g. oxygen consumption, biomass production, decomposition).

The structural and functional processes have to be quantified for thoroughly understanding the vegetation dynamics. The structural analysis of vegetation entails the floristic composition, stand density, basal area, vertical stratification and community types. While, the diversity provides information on species richness, distribution and rate of change in species composition (Adekunle, 2013), both structure and diversity of vegetation have strong functional role in controlling ecosystem process like biomass production, cycling of water and nutrients (Gower et al., 1992). Tree species diversity is an important aspect of forest ecosystem (Rennolls and Laumonier, 2000). Tree species inventories at defined sites and in minimum diameter classes give a reliable instrument to indicate the diversity level of a study site (Wattenberg and Breckle, 1995). Quantitative floristic sampling also provides the necessary context for planning and interpreting long term ecological research (Phillips et al., 2003). The long-term permanent plot and permanently tagged individuals of trees provide a unique opportunity to investigate the dynamics of individual species and total forest in space and time (Ayyappan and Parthasarathy, 1999). Such large-scale permanent plot studies are also important for conservation and management of tropical forests (Field and Vazquezyanes, 1993). Recently the number of permanent plots has increased rapidly in various tropical forests of the world (Hubbell and Foster, 1983; Manokaran et al., 1990; Sukumar et al., 1992; Ayyappan and Parthasarathy, 1999 and Sagar and Singh, 2003).

Plant diversity inventories in tropical forests have mostly been concentrated on tree species than the other life forms, because tree species diversity is an important aspect of forest ecosystem and also fundamental to total tropical forest biodiversity. 
They provide resources and habitat structure for almost all other species. Studies on tropical tree diversity have accumulated over the past decades and there is a great deal of interest to decipher the pattern and process relating to tropical forest diversity (Anita et al., 2010)

The vegetation's in Kano zoological garden combines a characteristic feature of Guinea and Sudan Savanna vegetation zones of Northern Nigeria, because the area is found in the vegetation transition zone of the Savanna. Vegetation resource contributes to the environmental and economic development of such an area, for the fact that plants contribute large percentage on human development, environmental and human sustainability. Their importance (plants) has made man to use them in a multi-purpose way. The plants of the Nigerian Savanna have ample uses. The works of Mortimore (1999) and Mohammed (1997) purely showed that, the Savanna plants contributed immensely in almost every sector of rural economy especially in the extreme Northern parts of Nigeria.

The density and biomass have direct effects on the functioning of ecosystem. In the course of millions of years, numerous biotic communities have evolved and established themselves. It is therefore important to know the diversity, similarities and species richness of these communities in space and time so as to understand their role in the development of the ecosystem, evolution and in the maintenance of stability. One of the measures of the well-being and stability of any ecosystem is the estimation of its species diversity and richness. The species diversity and richness values also indicate the nature of plants community in a region. For the quantification of diversity and comparison of species diversities between different ecosystems in various climatic conditions, it is useful to calculate an index of diversity and dominance. The index is usually calculated on the basis of the part to the whole such as $n / N$, where the $n$ is number or biomass, productivity or IVI to that of total value for all the species in that community. The commonly used biodiversity index is Shannon-Wiener Index and that of dominance index is Simpson Index.

Kano zoological garden was established about 37 years ago and has been under the control and supervision of the state government. It is located $3 \mathrm{~km}$ away from the old city of Kano about a mile off Kano-Zaria road, West of Gyadi-Gyadi Quarters in Gandun Albasa Kano municipal local Government Area. It covers about 100 acres and lies on latitude of $11.98 \mathrm{~N}$ and longitude $8.52 \mathrm{E}$. Kano zoological garden vegetation is densely rich in both exotic and indigenous plant species

\section{Sampling Method}

The study area was divided into two study sites on the basis of area; each site was measured 100 $X 100$ in length equivalent to one hectare to study the status of plant diversity. Quadrant sampling method was used; with the help of a meter rule, a quadrant of size $40 \mathrm{~m} \times 40 \mathrm{~m}$ was created and used for sampling of plant species.

\section{Data Collection and Analysis}

Vegetation data were collected by direct counting of plants species in the habitats. Quantitative analysis of woody vegetation for relative frequency, Density, relative density, abundance, similarity indices, diversity, Frequency and Dominance was done following procedure proposed by Misra, (1968). All the statistical analysis was carried out using Microsoft Excel, 2007.

Frequency

Frequency indicates the number of sampling units in which a species occurs. It refers to the degree of dispersion of individual species in an area and it is expressed in term of percentage of occurrence and calculated as follows:

Number of quadrants in which the species occurred X 100

Total number of quadrants studied

\section{Density}

Density is an expression of the numerical strength of a species where the total number of individuals of each species in all the quadrants is divided by the total number of quadrants studied. Density is calculated by the equation:

Total number of individuals of a species in all quadrants

Total number of quadrants studied

\section{Abundance}

It is the study of the number of individuals of different species in the community per unit area. By quadrants method, samplings are made at random at several places and the number of individuals of each species was summed up for all the quadrants divided by the total number of quadrants in which the species occurred. It is represented by the equation:

Total number of individuals of a species in all quadrants

Total number of quadrants in which the species occurred 


\section{Important Value Index}

This index is used to determine the overall importance of each species in the community structure. In calculating this index, the percentage values of the relative frequency, relative density and relative dominance are summed up together and this value is designated as the Importance Value Index or IVI of the species (Curtis, 1959).

\section{Relative density}

Relative density is the study of numerical strength of a species in relation to the total number of individuals of all the species and can be calculated as:

Number of individual of the species $\quad X 100$

Number of individual of all the species

Relative frequency

The degree of dispersion of individual species in an area in relation to the number of all the species occurred.

Number of occurrence of the species $X 100$

Number of occurrence of all the species

SPECIES RICHNESS

The species richness of the vascular plants was calculated by using the method of 'Margalef's index of richness' (Dmg) (Magurran, 1988)

Dmg $=\mathrm{S}-1$

$\operatorname{tn} N \quad$ Where $S$ is the total number of species and $\mathrm{N}$ is the total number of individuals

\section{Species Diversity Index}

The Shannon-Weiner diversity index (Shannon and Weiner, 1963) is commonly used to characterize species diversity in a community. The formula for calculating the Shannon diversity index is

$\mathrm{H}^{\prime}=-\Sigma p i$ Inpi

Where, $H^{\prime}$ = Shannon index of diversity

$P i=$ the proportion of important value of the ith species $(p i=n i / N, n i$ is the important value index of ith species and $\mathrm{N}$ is the important value index of all the species).

\section{Species Dominance Index}

The Simpson Index is an index of dominance whose maximum value is 1 , which is obtained in the case of a single species (complete dominance) and the near values are obtained when numerous species are present (no dominance), each species representing a small fraction of the total value.

Simpson (1949) index of Dominance:

The equation used to calculate Simpson's index was

$\mathrm{D}=\Sigma(p \mathrm{i})^{2}$

Where, $\mathrm{D}=$ Simpson index of dominance
$P i=$ the proportion of important value of the ith species $(p i=n i / N$, ni is the important value index of ith species and $\mathrm{N}$ is the important value index of all the species). As D increases, diversity decreases and Simpson's index was therefore usually. Expressed as 1 - D or 1/ D

\section{RESULTS}

Table 1.0 show the results obtained on primary ecological parameters. In study site A, Azadirachta indica was observed to have the highest population value of 115, followed by lantana camara with 81and Aeschynomene indica has 80 . While the least population value was recorded in Magnifera indica, Phoenix dactilifera and Tamarindus indica. While in study site B, Azadirachta indica was observed to have the highest population size of 92, followed by Lantana camara with 75 and Eucalyptus camaldulensis has 73. The least population values were obtained in Piliostigma reticulata and Delonix regia.

In terms of density, Azadirachta indica was observed to have the highest density value of $19.16 \%$, followed by Lantana camara, Boswelia dalziella and Aeschynomene indica with $13 \%$ each while the least density value was recorded in Phoenix dactilifera, Tamarindus indica and Ziziphus spina-christi. In study site B, Azadirachta indica has also recorded highest density value of $15.33 \%$, followed by Lantana camara and Eucalyptus camaldulensis with $12 \%$ each, while the least value was observed in Piliostigmareticulata and Delonix regia.

In study site A, Azadirachta indica was observed to have the highest relative density value of $9.64 \%$. It was followed by Lantana camara $6.79 \%$, Boswelia dalziella and Aeschynomene indica with $6.71 \%$ each, while the least value was recorded in Phoenix dactilifera $0.58 \%$ and Tamarindus indica $0.67 \%$. With regards to study site B, Azadirachta indica was also observed to have the highest relative density value of $9.43 \%$ and it was followed by Lantana camara with about $7.69 \%$, and Eucalyptus camaldulensis with $7.48 \%$ while the least was recorded in Piliostigma reticulata and Delonix regia.

In study site A, Aeschynomene indica was observed to be the most abundant species and was followed by Lantana camara while the least value were Magnifera indica and Phoenix dactylifera. For study site B, Azadirachta indica was the most Abundant value and it was followed by Albizia lebbeck, Ficus thonningii and Aeschynomene indica, while the least abundant were Dalbergia sissoo and Ficus sycomorous 
Special Conference Edition, November, 2018

Percentage frequency of study site A has indicated that Azadirachta indica and Gmelina arborea have greater percentage when compared to Adansonia digitata, Phoenix dactilifera, Tamarindus indica,

Magnifera indica, Cascabela thevetia, Ziziphus spina-christi and
Aeschynomene indicawith. In study site B, Acacia nilotica was observed to have the highest value of $83.33 \%$. and the least value was recorded in Delonix regia, Vitex doniana,Piliostigma reticulata,

Albizia lebbeck, and Ficus thonningii.

TABLE 1.0 Primary Ecological Parameters of Kano Zoological Garden

\begin{tabular}{|c|c|c|c|c|c|c|c|}
\hline $\mathrm{S} / \mathrm{N}$ & $\begin{array}{l}\text { PLANT SPECIES } \\
\text { SCIENTIFIC NAME }\end{array}$ & $\begin{array}{l}\text { NO OF } \\
\text { INDIVIDUALS }\end{array}$ & $\begin{array}{l}\text { NO. OF QUADRANTS THE } \\
\text { SPECIES OCCUR }\end{array}$ & DENSITY & \%FREQUENCY & ABUNDANCE & R.DENSITY \\
\hline 1 & Azadirachta indica & 115 & 5 out of 6 & 19.16 & 83.33 & 23.00 & 9.64 \\
\hline 2 & Adansonia digitata & 16 & 2 out of 6 & 2.66 & 33.33 & 8.00 & 1.34 \\
\hline 3 & Delonix regia & 39 & 4 out of 6 & 6.50 & 66.66 & 9.75 & 3.27 \\
\hline 4 & Dalbergia sissoo & 42 & 3 out of 6 & 7.00 & 50.00 & 14.00 & 3.52 \\
\hline 5 & Phoenix dactilifera & 07 & 2 out of 6 & 1.16 & 33.33 & 3.50 & 0.58 \\
\hline 6 & Vitex doniana & 30 & 3 out of 6 & 5.00 & 50.00 & 7.50 & 2.51 \\
\hline 7 & Tamarindus indica & 08 & 2 out of 6 & 1.33 & 33.33 & 4.00 & 0.67 \\
\hline 8 & Ficus sycomorus & 40 & 3 out of 6 & 6.67 & 50.00 & 13.33 & 3.35 \\
\hline 9 & Khaya senegalensis & 58 & 3 out of 6 & 9.67 & 50.00 & 19.33 & 4.86 \\
\hline 10 & Piliostigma reticulata & 47 & 3 out of 6 & 7.83 & 50.00 & 15.66 & 3.94 \\
\hline 11 & Magnifera indica & 05 & 2 out of 6 & 0.83 & 33.33 & 2.50 & 0.41 \\
\hline 12 & Lannea acida & 40 & 4 out of 6 & 6.67 & 66.66 & 10.00 & 3.35 \\
\hline 13 & Gmelina arborea & 55 & 5 out of 6 & 10.83 & 83.33 & 16.25 & 5.45 \\
\hline 14 & Acacia senegalensis & 72 & 4 out of 6 & 12.00 & 66.66 & 14.40 & 6.04 \\
\hline 15 & Cascabelathevetia & 49 & 2 out of 6 & 8.16 & 33.33 & 24.50 & 4.11 \\
\hline 16 & Lantana camara & 81 & 3 out of 6 & 13.50 & 50.00 & 27.00 & 6.79 \\
\hline 17 & Taminalia latiflora & 69 & 4 out of 6 & 11.5 & 66.66 & 17.25 & 5.78 \\
\hline 18 & Acacia seyal & 59 & 4 out of 6 & 9.83 & 66.66 & 14.75 & 4.94 \\
\hline 19 & Boswelliadalziella & 80 & 4 out of 6 & 13.33 & 66.66 & 20.00 & 6.71 \\
\hline 20 & Albizia lebbeck & 62 & 4 out of 6 & 10.33 & 66.66 & 15.50 & 5.20 \\
\hline 21 & Ziziphus spina christi & 09 & 2 out of 6 & 1.50 & 33.33 & 4.50 & 0.75 \\
\hline 22 & Tectona grandis & 47 & 3 out of 6 & 7.83 & 50.00 & 15.666 & 3.94 \\
\hline 23 & Aeschynomene indica & 80 & 2 out of 6 & 13.33 & 33.33 & 40.00 & 6.71 \\
\hline 24 & Acacia nilotica & 72 & 4 out of 6 & 12.00 & 66.66 & 18.00 & 6.04 \\
\hline
\end{tabular}

Secondary ecological parameters

The averages of the values obtained from the primary ecological parameters in both study sites were used to determine the secondary ecological parameter and based on the frequency distribution of the species, Raunkiaer (1934) classified a community into five frequency (\%) classes viz. $A=1-20 \%, B=21-40 \%, C=41-60 \%, D=61-80 \%$ and $E=81$ $100 \%$. Raunkiaer presented his law of frequency, portraying a bimodal occupancy frequency distribution (OFD) in undisturbed plant communities. 
Special Conference Edition, November, 2018

Table 1: Frequency class distribution of plant species in study site $A$ and study site $B$

Frequency classes Study site A Study site B

\begin{tabular}{|c|c|c|c|c|}
\hline 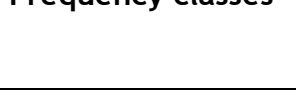 & No. of species & $\begin{array}{l}\% \text { of total no. of } \\
\text { species }\end{array}$ & No. of species & $\begin{array}{l}\% \text { of total no. of } \\
\text { species }\end{array}$ \\
\hline $\begin{array}{c}\text { A- } 1-20 \% \\
B-21-40 \% \\
C-41-60 \% \\
D-61-80 \% \\
E-81-100\end{array}$ & $\begin{array}{c}0 \\
7.0 \\
7.0 \\
8.0 \\
2.0 \\
\end{array}$ & \begin{tabular}{c|}
$0 \%$ \\
$45 \%$ \\
$45 \%$ \\
$8.0 \%$ \\
$2.0 \%$ \\
\end{tabular} & $\begin{array}{c}0 \\
5.0 \\
4.0 \\
9.0 \\
1.0\end{array}$ & \begin{tabular}{c|}
$0 \%$ \\
$6.0 \%$ \\
$4.0 \%$ \\
$89 \%$ \\
$1.0 \%$ \\
\end{tabular} \\
\hline $\begin{array}{l}\text { Table 2: Abundar } \\
\text { Abundance classes }\end{array}$ & Study sit & & Study & \\
\hline & No. of species & $\begin{array}{l}\text { \%of total no. of } \\
\text { species }\end{array}$ & No. of species & $\begin{array}{l}\% \text { of total no. of } \\
\text { species }\end{array}$ \\
\hline Rare $1-4$ & 0 & $0 \%$ & 4.0 & $4 \%$ \\
\hline Occasional 5 - 14 & 9.0 & $45 \%$ & 8.0 & $20 \%$ \\
\hline Frequent 15 - 29 & 10.0 & $55 \%$ & 11.0 & $75 \%$ \\
\hline Abundant $30-90$ & 0 & $0 \%$ & 1.0 & $1 \%$ \\
\hline Very abundant $100+$ & 0 & $0 \%$ & 0 & $0 \%$ \\
\hline
\end{tabular}

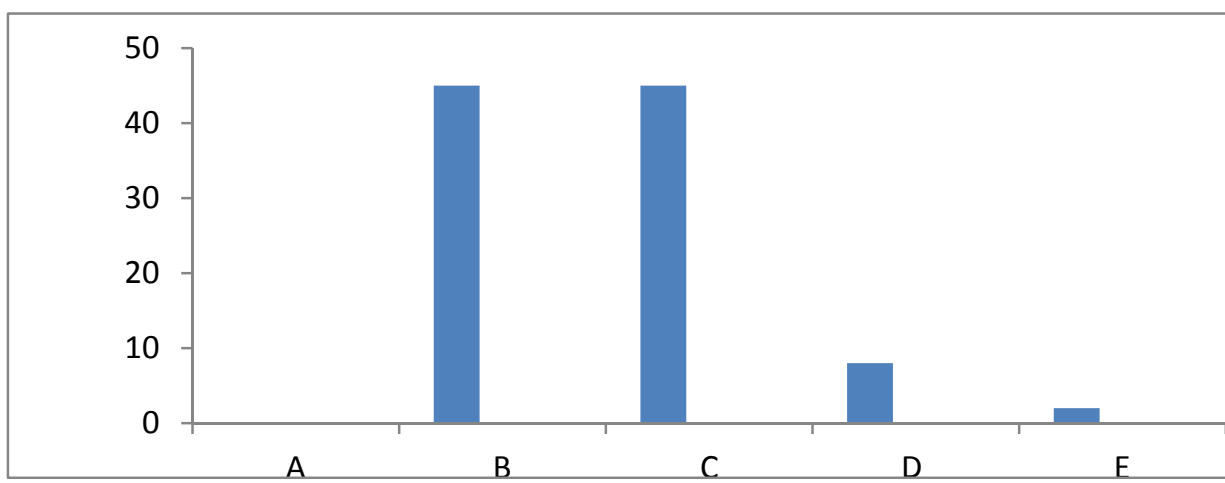

Fig 1: Raunkiaer percentage frequency distribution class in study site $A$

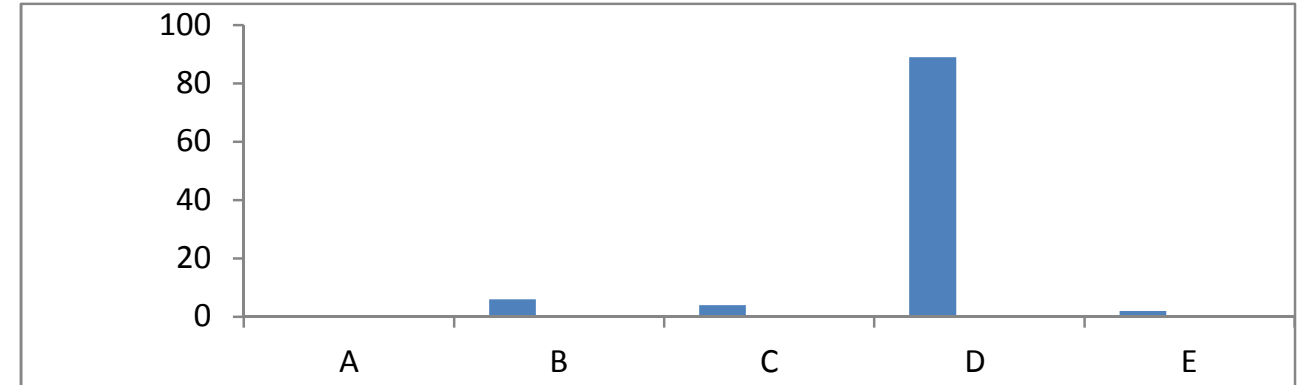

Fig 2: Raunkiaer percentage frequency distribution class in study site $B$

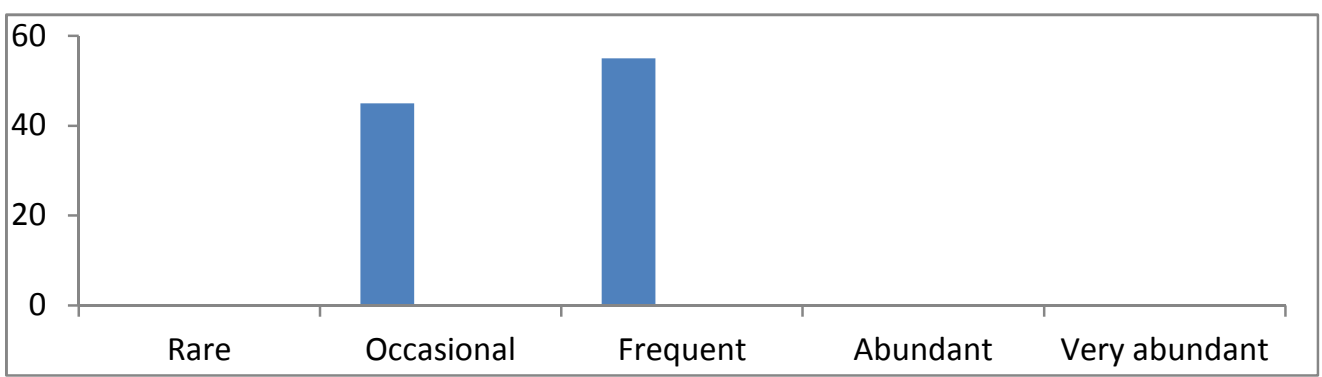

Fig 3: Species abundance for study site A

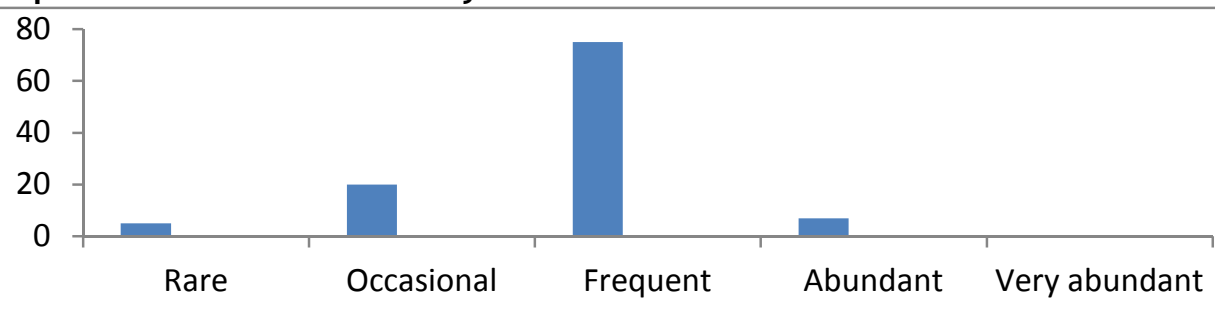

Fig 4: Species abundance for study site $B$ 
Special Conference Edition, November, 2018

The simplest species richness index is based on the total number of species and the total number of individuals in a given sample or habitat and it indicates, the higher the value, the greater the species richness. In the present study, the Margalef index of species richness in study $A$ was higher (3.26) than in study site B (2.62).

Shannon index of diversity ranges from $1-5$ and evenness ranges from 0-5. From the calculation of Shannon index of diversity and evenness, the result obtain showed that there is high diversity of plant species in study site A with the value of (2.8) and low evenness with the value of $(0.89)$. Similar trend was also observed in study site B.

The Simpson index of dominance was 0.95 in study site $A$ and 0.52 in study site $B$. The Simpson index revealed that the level of dominance was higher in study site $A$ in comparison to that in the study site $B$.

\section{REFERENCES}

Adekunle, V.A.J., Olagoke, A.O. and Akinele, S.O. (2013). Tree species diversity and structure of a Nigerian strict nature reserve. Tropical Ecology, 54:275-289.

Anita K, Joseph S, Chandran R.J, Ramasamy EV, Prasad SN. (2010). Tree species diversity and community composition in a human-dominated tropical forest of Western Ghats biodiversity hotspot, India. Ecological Complexity 7:217-224.

Ayyappan N, Parthasarathy. (1999). Biodiversity inventory of trees in a large-scalepermanent plot of tropical evergreen forest at Varagalair, Anamalais, WesternGhats, India. Biodiversity and Conservation 8:1533-1554.

Champion H.G. and Seth, S.K. (1968). A revised survey of the forest types of India. New Delhi: Government of India Publications.

Curtis J.T, Mclntosh RP. (1980). The interrelations of certain analytic and synthetic phytosociological characters. Ecology 31:434-455.

Curtis, J.T. and Cottam, G. (1959). Plant Ecology Workbook Laboratory Field Reference Manual. Burgess Publishing Co. Minnesota Curtis, J.T. and Mc Intosh, R.P. (1951). An upland forest continuum in the Prairie forest border region of Wisconsin, Ecology, 32: 476-496

Field, A.O. and vazquezyanes, A.R.R. (1993). Vegetation characteristics of southern secondary moist mixed deciduous forests of Agasthyamalai region of Kerala. Indian Journal of Forestry, 21(4): 639644.

Gower, S.T., Vogt, K.A. and Grier, C.C. (1992). Influence of water and nutrient availability. Ecological Monographs, 62(1): 43-65.

Hubbell, S. P. \& R. B. Foster. (1983). Diversity of canopy trees in a neotropical forest and implications for conservation. pp. 25-41. In: Tropical rainforest: ecology and management. Sutton, S.L., T. C. Whitmore \& A. C. Chadwick (eds.). Lacknell Scientific Publishers, Oxford.

Magurran, A.E. (1988). Ecological Diversity and its measurements, Croom, Hem.

Manokaran N, Condit R, Hubbell SP, La Frankie JV, Sukumar R, Foster RB, Ashton PS.(1996). Speciesarea and species individual relationships for tropical trees: a comparison of three 50 -ha plots. Journal of Ecology 84:549-562.

\section{CONCLUSION}

For the quantitative analysis of Kano Zoological Garden, a total of 1927 estimated individual plants belonging to 24 genera and 14 families were recorded from the selected study sites. Hence, the vegetation of Kano Zoo exhibits that of Sudan savanna vegetation. Higher frequency percentages were observed in Azadirachta indica, Gmelina arborea, Taminalia latifolia, acacia seyal, Boswelia dalziella, Eucalyptus camaldulensis, Acacia nilotica. The most dominant plant family is Fabaceae in the study sites and the commonest genera are Acacia, Aeschynomene, Delonix and Tamarindus. The research also showed that other parameters like frequency distribution and species abundance clearly portrayed that the study site B was under anthropogenic pressure and if the present trend continues, the site might lose its diversity completely in recent times.

Misra, R. (1968). Ecology work book, Oxford and IBH Publications Co., New Delhi, 244

Mohammed, S. (1997). Conditions of Access, Use and Management of Trees, Shrubs and Grasses in the semi-arid region of Northern Nigeria: Unpublished Msc thesis. Bayero University, Kano, Nigeria.

Mortimore, M. and William, M. A. (1999). Working the Sahel. Environment and Society in Northern Nigeria. Routldge, London, UK.

Okereke, C.N., Nnabude, P.C., Mbaekwe, E.I., Ekwealor, K.U., Uhuao, C.A. and Nwanchor, K.C. (2014) the use of ecological methods in vegetative studies of plant species and abundance in south-eastern Nigeria. African journal of plant science, 8(9)441-449

Phillips, O. L., P. Hall, A. H. Gentry, S. A. Sauyer \& R. Vasquez. (2003). Dynamics and species richness of tropical rainforests. Proc. National Acad. of Sciences of the USA. 91: 2805-2809.

Raunkiaer, C. (1934). The life forms of plants and statistical plant geography, Clarendon

Rennolls, K. \& Laumonier, Y. (2000) Species diversity structure analysis at two sites in the tropical rain forest of Sumatra. Journal of Tropical Ecology, $16,253-270$.

Sagar R, Singh J.S. (2006). Tree density, basal area and species diversity in a disturbed dry tropical forest of northern India: implications for conservation. Environmental Conservation 33:256-262.

Shannon, C.E. and Wienner, W. (1963). The Mathematical Theory of Communication,

Sorensen, T. (1948). A method of establishing groups of equal amplitude in plant Structure and floristic composition of flood plain forests in the Peruvian Amazon: I. Survey. India, Kolkata

Sukumar, R., B. S. Dattaraja, H. S. Suresh, J. V. Radhakrishnan, R. Vasudeva, S. Nirmala \& N. V. Joshi. (1992). Long-term monitoring of vegetation in a tropical deciduous forest in Mudumalai, southern india. Current Science. 62: 603-616.

Wattenberg, I. \& Breckle. S., (1995). Tree species diversity of a premontane rain forest in the Cordillera de Tilaren, Costa Rica. Biotropica 1: 21-30. 